\title{
THEORETICAL ASPECTS REGARDING INTERNAL MANAGERIAL CONTROL IN MILITARY ORGANIZATIONS
}

\author{
Valentin PÎRVUȚ \\ “Nicolae Bălcescu” Land Forces Academy, Sibiu, Romania \\ pirvut_v@yahoo.com \\ Alin Teodor HUSERAŞ \\ “Nicolae Bălcescu” Land Forces Academy, Sibiu, Romania \\ huseras.alin@gmail.com
}

\begin{abstract}
The goal of this paper is to offer synthetically theoretical support regarding the exertion of internal managerial control in the state's public institutions. The activity of managerial control must be understood and regarded as an activity integrating all forms of control exercised at the level of the institution with a view to ensuring a better functioning of the managerial sphere, making the managerial act accountable at every level and structure. Once the internal managerial control is implemented, the responsibility of management is that of identifying all the deviations from the objectives noticed at the end of the control activities, of analysing the causes that determined their appearance and of deciding upon the necessary preventive and corrective measures.
\end{abstract}

KEYWORDS: System of internal managerial control, Internal Managerial Control Code, general good practice principles, efficient economic administration, program of development, procedures, objectives, standards

\section{Introduction}

The challenges of globalisation and of continuous economic development require better management at the level of public institutions that are faced with this dynamic development. At the community level, this assumption led to the emergence of the concept of competitive public administration through which the assigned tasks and objectives could be carried out with maximum efficiency, in an independent, responsible and transparently guided manner and according to the highest standards of responsibility.

In order to achieve the standardization and uniformity of internal control system, the Internal Managerial Control Code of public entities was drawn up, being built on the community acquis in the field of managerial control and formed 
from internationally accepted general principles of good practice. Each country maintains its legislative, administrative and cultural specificity regarding the manner in which these principles are applied in the internal control systems.

In the context of the general good practice principles, internal control has a large acceptance, being regarded as a managerial function, not an operation of verification. By exerting the control function, management notices the deviations of results from the established objectives, analyses the causes producing them and orders the required corrective and preventive measures (Guvernul României, 2015).

In spite of the fact that the internationally and nationally established definitions given to the internal control system are numerous (European Commission, INTOSAI, Public Entities Commission for the Sponsoring of Treadway Commission (S.U.A.) - COSO, Canadian Institute of Authorized Accountants Control", Law no. 672/2002, G.O. no. 119/1999), they are not contradictory, all of them stating that there is not a single operation but an ensemble of devices implemented by the persons responsible at all the levels of the organization in order to have control over all the internal processes that are carried out in achieving the general and specific objectives and over appropriate functioning.

\section{Generalities Regarding Internal Managerial Control}

At national level, the necessity and obligativity of organizing internal control in public entities are specified by Romanian Government (GR) since 1999 in the Government Ordinance no. 119 regarding internal/managerial control and preventive financial control, which defines it as an "ensemble of forms of control exercised at the level of public entities, including internal audit, established by management in accordance with its objectives and legal regulations in order to ensure public funds administration in an economical, efficient and effective manner" (GR, 1999).

Internal managerial control is defined as the totality of the elements that make up the control system within the public entities, developed and implemented at the level of organizational structures and presented through operational methods and procedures established by the manager in accordance with the objectives of the organization and the legal regulations for an efficient and effective administration of public funds (GR, 1999).

Ordinance no. 119/1999 defines the effective administration as the extent to which the objectives established for the specific activities assumed by the institution are achieved or as a rapport between the designed effect and the obtained effective result of the respective activity. Efficient administration represents the maximization of the results of an activity in relation to the resources used by the institution. Being economical refers to minimizing the cost of the resources allotted for the achievement of the proposed results while maintaining suitable quality standards.

Taking into account the above mentioned terms, public entities managers have to attain a good financial management through the implementation of legal regulations, the elaboration, approval and improvement of the system and operational procedures, the elaboration of an internal managerial control evaluation report, the identification of downfalls and decision on the required correction measures.

\section{Internal Managerial Control Characteristics}

3.1. The concept of internal managerial control aims at achieving performance of duties of public institutions established in terms of regularity, efficiency, economy and effectiveness based on their mission in the best conditions to protect public funds against 
losses due to error, waste, abuse or fraud and in compliance with all applicable laws.

3.2. The following are the general and specific internal/managerial control requirements (GR, 1999):

a) general requirements:

- ensuring the fulfilment of the overall objectives through the systematic evaluation and maintaining an acceptable level of risk associated with the operations;

- ensuring a collaborative attitude between management and executive staff;

- ensuring the integrity and competence of staff with the role of internal/managerial control;

- establishing specific objectives of internal control/management so that they are appropriate, comprehensive, reasonable and integrated into the mission of the institution and its objectives;

- continuous supervision by managers of all activities and responsible application and prompt corrective action whenever it finds violations of legality in carrying out transactions or performing activities.

b) specific requirements:

- documented in written form for organizing and conducting internal control management of all operations;

- control operations carried out exclusively by persons empowered to do so, other than the persons responsible for approval and registration;

- ensuring competent leadership at all levels;

- accessing resources and documents only by persons entitled and responsible in connection with their use and storage.
3.3. "Public Internal Financial Control Strategy in Romania for the period 2014-2016" elaborated by Ministry of Public Finance (MF) in 2014, provides the legislative framework as a total of 25 standards of internal control/ management, harmonizing the good practices in the field. These internal control standards represent a frame of reference in relation to which internal control systems are self-evaluated, risk areas are identified and possible corrective measures are established differently from one public entity to another, depending on the specific organizational culture (MF, 2014a).

Depending on the criteria specific to each standard they can be considered to be implemented, partially implemented or not implemented for each structure, and depending on the number of implemented standards the degree of compliance of the internal control/managerial system set is determined.

The measures required for the implementation of an appropriate internal/managerial control are mainly the following:

- the ruler of the public entity constitutes a "monitoring committee", comprising a president and heads of departments of the organizational structure to monitor, coordinate and direct the methodological development and implementation of internal control management in order to develop and update "Program of development of the internal managerial control system" (objectives, activities, timelines, responsibilities - in interdependence with the mission and organizational structure of the public entity) and the development or updating of "formalized procedures/system/operational" on various activities at risk (GR, 2015).

- at the level of compartments, a person is appointed responsible for the risks involved in training in risk management and advising staff of the 
department, as well as develop the "Register of risks on compartments" (GR, 2015);

- monitoring the implementation of the actions/measures included in the programs for the development of internal/managerial control systems or the existing procedures and how to apply them;

- staff participation in professional training activities;

- performing analyses regarding the implementation/development of the managerial control systems;

- creating the managerial control system self-evaluation involves the assessment of the implementation of each standard separately by each compartment and then an overall assessment of the entity's annual report, which is the official form of managerial accountability on the control internal/managerial system, report that is presented as an annex to the financial situation of the concluded budget exercise.

\section{Structural and Organizational Elements of the Internal Managerial Control System}

The organization of the internal managerial control system of each public entity has in view the achievement of three categories of permanent objectives (positive effects that management seeks to achieve or negative events they are trying to avoid), which can be grouped as follows:

a) objectives regarding the effectiveness and operating efficiency which aim at achieving the public entity goals and the use of public funds in conditions of economy, effectiveness and efficiency by protecting the entity's resources against misuse, loss or fraud;

b) objectives on the reliability of internal and external information - pursuing an adequate accounting system and enhanced quality of information used, as well as their protection against two types of fraud: fraud concealment and distortion of results;

c) objectives relating to the compliance with laws, regulations and internal policies aimed at ensuring that the entity's operations are conducted in conditions of legality and regularity with laws, regulations and internal procedures (authorization and approval, separation of duties, access to resources and documents, verification, operating performance analysis, review of the processes, operations and activities, supervision, etc.).

The design, implementation and continuous development of a viable system of internal control is only possible if the system meets the following requirements:

a) it is adapted to the size, complexity and environment specific to the entity;

b) it involves all levels of management, all activities and all operations;

c) it is constructed with the same "instruments" (based on objectives, resources, information system, organization, procedures, control) in all public entities having the same profile;

d) it provides reasonable assurance that the entity's objectives will be achieved;

e) the costs of applying internal control system are lower than the resulted benefits;

f) it is guided by the minimum management rules contained in the standards in the field.

The internal managerial control system of any public entity must operate with a variety of methods, means and actions, provisions concerning all aspects of the entity's activities which require efforts by all staff of the entity, especially by management employees.

The internal control managerial activities are part of the management focused on achieving objectives, goals which are:

a) general are targets established at the level of the public entity for the medium or long term, listed in the organization and functioning law or established in the strategic plan and policies; 
b) individual are quantitative or qualitative expressions of the purpose for which the respective post was created and operates, carried out through the tasks as a result of professional competence, the formal decision-making autonomy and authority of the person employed in that post;

c) specific, derived from the specific objectives and activities and constituting intermediate targets for the accomplishment of the overall objective.

In order to standardize and create a uniform and coherent internal managerial control model, allowing comparisons between entities of the same kind, the Order no. 400/2015 for the approval of the Code of internal managerial control of public entities establishes a list of 16 managerial ICS public entities. The standards are a benchmark against which the internal managerial control systems are assessed and the areas and directions of change are identified.

The purpose of internal managerial control standards is to create a model of control and define the minimum management rules that public entities must follow, taking into account the organizational specificity.
The standards are grouped according to five key-elements of the internal managerial control (GR, 2015):

- the control environment including the issues related to organization, human resources management, ethics, deontology and integrity;

- performance and risk management, targeting the issues of setting objectives, planning (annual planning), software (management plan) and performance;

- control activities focused on: documentation of procedures; continuity of operations; recording of exceptions; separation of powers; supervision, etc.;

- information and communication, bringing together the issues related to creating an adequate information system and a system of reports on the implementation of the management plan, budget, use of resources, and management of documents;

- evaluation and audit, involving the development of the evaluation capacity of the internal managerial control in order to ensure continuity in the process of improving it.

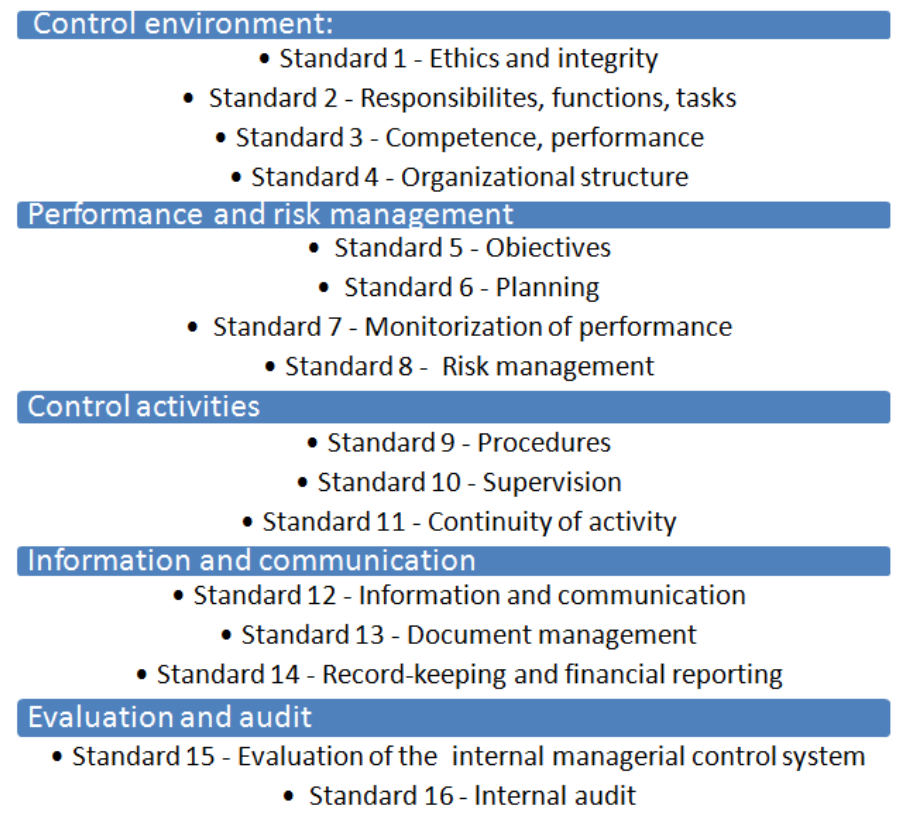

Figure no. 1 Internal managerial control standards grouping according to the five key-elements (Source: Romanian Government, 2015) 
Each standard of control is structured on three components:

- description of the standard presenting the defining characteristics of the management field to which the standard and the field set through its title refer;

- general requirements - presenting the major directions for action with a view to respecting the standard;

- principal references - listing the representative normative acts, which contain the regulations applicable to the standard, but do not have an exhaustive character.

\section{Particularities of Internal Managerial Control in the Military Organization}

The internal managerial control system within the military organizations is organized in such a way so as ensure the accomplishment of the following three categories of permanent objectives:

-efficacy and efficiency of functioning;

- reliability of internal and external information;
- conformity with the internal laws, rules and policies.

An increased focus is also laid on the ethical counselling of military personnel and contractual civilian staff, with a view to promoting the ethical values, as well as the values specific to Romania's Army.

In the internal managerial control within the military organization, special attention is paid to establishing the posts considered particularly subject to corruption, taking into consideration the functional attributes that usually involve:

- access to classified information or to not classified information excepted from the free access of citizens;

- managing resources;

- level of decision and the consequences of the decisional act;

- exclusive decisional competence;

- running of public acquisitions procedures;

- direct relations with citizens and/or public or private institutions.

The implementation of internal managerial control can be performed according to the process diagram presented below:

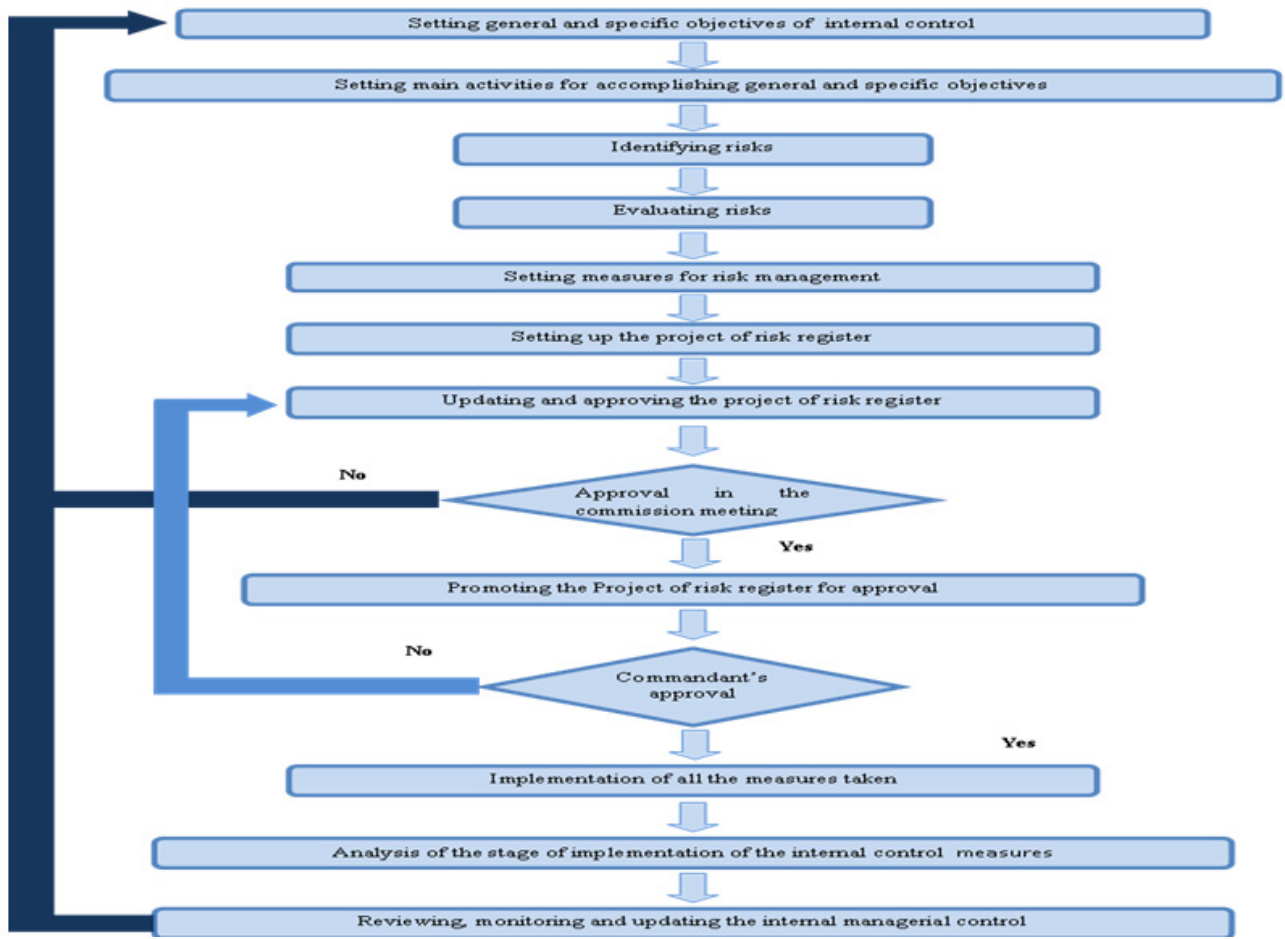

Figure no. 2 The Process of internal managerial control (Source: Romanian Government, 2015) 
6. Conclusions

It is important to note that the effectiveness of internal controls contributes to increasing the credibility of public institutions and to ensuring the use of public funds in conditions of economy, efficiency and effectiveness, also increasing the quality of financial reports.

In order to increase the quality of public entity activity, as well as the performance of the managerial act with regard to the use of public resources, it is necessary that:

- the accountability of managers should be increased in terms of internal control organization and implementation of measures and remedies on the dysfunctions observed during the inspection in order to strengthen the organization and improve the managerial activity;

- responsibilities should be set for all the heads of structures and compartments with regard to all the important activities representing the process of management, which ensure high performance of the managerial act at all levels and domains of the entity;

- internal control should be involved in creating procedures where there are none and the existing procedures should by systematically updated according to the legislative changes and the evolution of the identified risks.
The internal control system does not represent only policies, plans, programs, procedures, operations, instructions, techniques, forms and documents, but also the entire organization staff that must be aware, educated and actively involved in this process, each member of the entity being responsible for its internal control.

In practice, the system of internal control functions in an environment of continuous change, which requires the adaptation of the control to the level of each activity, differently and interactively, according to the interests of the organization. Exceeding the norms, rules and procedures hampers an efficient control, therefore it is necessary that an optimum balance should be found in establishing them.

Thus, there are situations in which precise, clear, strict rules are required in order to achieve the strategic objectives of the entities.

The manner of establishing these rules pertains, on the one hand, to the leadership style and the capabilities of the hierarchical bodies in delegating responsibilities and, on the other hand, on the level of development of the organizational and managerial culture of the entities.

A greater flexibility is required in organizing and exercising internal control since rules cannot be set for each situation encountered or yet not encountered. Also a rule hampers the process if it is not updated or too rigid, leading to inefficiency and inefficacy.

\section{REFERENCES}

Guvernul României. (1999). Ordonanţa nr. 119 din 31 august 1999, privind Controlul intern şi controlul financiar preventiv. Bucureşti: Monitorul oficial.

Guvernul României. (2015). Ordinul nr. 400 din 12 iunie 2015 pentru aprobarea Codului controlului intern managerial al entităţilor publice. București: Monitorul oficial.

Guvernul României. (2016). Ordin nr. 201 din 26 februarie 2016 pentru aprobarea Normelor metodologice privind coordonarea, îndrumarea metodologică şi supravegherea stadiului implementării şi dezvoltării sistemului de control intern managerial la entităţile publice. Bucureşti: Monitorul oficial.

Ministerul de Finanţe. (2014a). Strategia Dezvoltării Controlului Financiar Public Intern în România pentru perioada 2014-2016. Bucureşti: Monitorul oficial. Ministerul de Finanţe. (2014b). Manualul de Control Financiar Preventiv. Bucureşti: Author 